\title{
Colorectal Cancer pN1a TNM Finding v7
}

National Cancer Institute

\section{Source}

National Cancer Institute. Colorectal Cancer pN1a TNM Finding v7. NCI Thesaurus. Code C89950.

Colorectal cancer with metastasis in one regional lymph node. (from AJCC 7th Ed.) 